\title{
A new genus and four new species of dactylogyrids (Monogenea), gill parasites of pimelodid catfishes (Siluriformes: Pimelodidae) in South America and the reassignment of Urocleidoides megorchis Mizelle et Kritsky, 1969
}

\author{
Aline A. Acosta ${ }^{1,2}$, Carlos A. Mendoza-Palmero ${ }^{1,3}$, Reinaldo J. da Silva ${ }^{2}$ and Tomáš Scholz ${ }^{1}$ \\ ${ }^{1}$ Institute of Parasitology, Biology Centre of the Czech Academy of Sciences, České Budějovice, Czech Republic; \\ ${ }^{2}$ São Paulo State University (UNESP), Institute of Biosciences, Department of Parasitology, Botucatu, São Paulo, Brazil; \\ ${ }^{3}$ Department of Botany and Zoology, Faculty of Science, Masaryk University, Brno, Czech Republic
}

\begin{abstract}
Nanayella gen. n. is proposed to accommodate four new species of dactylogyrid monogeneans found on the gills of two species of pimelodid catfishes (Siluriformes) from the Amazon River basin in Peru and the Upper Paraná River basin in Brazil. Nanayella gen. $n$. is mainly characterised by the presence of modified hook pairs 5 and 6 , which have a slender shank with slightly enlarged base, inconspicuous thumb, and straight point. Nanayella aculeatrium gen. n. et sp. n. (type species) from Sorubim lima (Bloch et Schneider) (type host) differs from its congeners mainly by possessing seven sclerotised spines on one side of circular ornamentation of the vaginal atrium. Nanayella fluctuatrium gen. $n$. et sp. $n$. is characterised by the presence of sclerotised undulations surrounding the circular ornamentation of the vaginal atrium. Nanayella amplofalcis gen. n. et sp. n. is typified by possessing hook pairs 1 and 2 with a robust, wide shank and a round, weakly sclerotised subunit at the base. Nanayella processusclavis gen. $n$. et sp. n. differs from congeners by the presence of a conspicuous posterior medial process on the dorsal bar. Urocleidoides megorchis Mizelle et Kritsky, 1969 described from the gills of S. lima in Brazil is transferred to Nanayella gen. n. as Nanayella megorchis comb. n. based on morphological and molecular evidence. Analyses of partial sequences of the 28S rRNA gene revealed all five species of the new genus to form a monophyletic clade within a bigger clade comprised of dactylogyrids of South American pimelodids.
\end{abstract}

Keywords: Ancyrocephalinae, morphology, integrative taxonomy, 28S rRNA, Sorubiminae, Neotropical region

This article contains supporting information (S1-S2) online at http://folia.paru.cas.cz/supp1/2019-66-004.pdf

The Pimelodidae (Siluriformes) represents a diverse and abundant monophyletic group of freshwater fishes, with 31 recognised genera including 112 valid species, distributed exclusively in South America, showing the highest species diversity in the Amazon, Paraná and Orinoco River basins (Lundberg and Littmann 2003, Lundberg et al. 2011, Eschemeyer et al. 2017). Pimelodids harbour the richest diversity of dactylogyrid monogeneans compared to that of other siluriforms in South America, with 44 species belonging to eight genera (Table 1). The porthole shovelnose catfish Hemisorubim platyrhynchos (Valenciennes) and the duckbill catfish Sorubim lima (Bloch et Schneider) share their distribution in the Amazon, Orinoco and Paraná River basins, but $H$. platyrhynchos is also present in the Maroni River (Suriname) and S. lima in the Parnaíba River, northern Brazil (Froese and Pauly 2018). These two fish species belong to the subfamily Sorubiminae (see Lundberg et al. 2011).

Even though the dactylogyrid fauna of pimelodids is rich and diverse (see Cohen et al. 2013, Aguiar et al. 2017), only Urocleidoides megorchis Mizelle et Kritsky, 1969 and Ameloblastella unapioides Mendoza-Franco, Mendoza-Palmero et Scholz, 2016 have been described from $S$. lima (see Mizelle and Kritsky 1969, Mendoza-Franco et al. 2016), and Vancleaveus platyrhynchi Kritsky, Thatcher et Boeger, 1986 from H. platyrhynchos (see Kritsky et al. 1986, Mendoza-Palmero et al. 2012).

Based on morphological and molecular evidence, this study proposes a new genus to accommodate four new species of dactylogyrids found on the gills of S. lima and $H$. platyrhynchos. In addition, U. megorchis from S. lima, which was considered as incertae sedis by Kritsky et al. (1986), is transferred to the new genus. 
Table 1. List of dactylogyrids described for pimelodid catfishes from South America.

\begin{tabular}{|c|c|c|c|}
\hline Species & Host & Country & Reference \\
\hline $\begin{array}{l}\text { Ameloblastella edentensis Mendoza-Franco, Mendoza- } \\
\text { Palmero et Scholz, } 2016\end{array}$ & Hypophthalmus edentatus Spix et Agassiz & Peru & Mendoza-Franco et al. (2016) \\
\hline $\begin{array}{l}\text { Ameloblastella formatrium Mendoza-Franco, Mendoza- } \\
\text { Palmero et Scholz, } 2016\end{array}$ & Pimelodidae gen. sp. & Peru & Mendoza-Franco et al. (2016) \\
\hline Ameloblastella mamaevi (Kritsky et Thatcher, 1976) & Zungaro zungaro (Humboldt) & Colombia & Kritsky et al. (2000) \\
\hline $\begin{array}{l}\text { Ameloblastella paranaensis (França, Isaac, Pavanelli et } \\
\text { Takemoto, 2003) }\end{array}$ & Iheringichthys labrosus (Lütken) & Brazil & Mendoza-Franco and Scholz (2009) \\
\hline $\begin{array}{l}\text { Ameloblastella peruensis Mendoza-Franco, Mendoza- } \\
\text { Palmero et Scholz, } 2016\end{array}$ & Hypophthalmus sp. & Peru & Mendoza-Franco et al. (2016) \\
\hline Ameloblastella platensis (Suriano et Incorvaia, 1995) & Pimelodus maculatus Lacepède & Argentina & Kritsky et al. (2000) \\
\hline Ameloblastella satoi Monteiro, Kritsky et Brasil-Sato, 2010 & Pimelodus maculatus & Brazil & Monteiro et al. (2010) \\
\hline $\begin{array}{l}\text { Ameloblastella unapioides Mendoza-Franco, Mendoza- } \\
\text { Palmero et Scholz, } 2016\end{array}$ & Sorubim lima (Bloch et Schneider) & Peru & Mendoza-Franco et al. (2016) \\
\hline Amphocleithrum paraguayensis Price et Romero, 1969 & Pseudoplatystoma sp. & Paraguay & Price and Romero (1969) \\
\hline Cosmetocleithrum longivaginatum Suriano et Incorvaia, 1995 & Pimelodus albicans (Valenciennes) & Argentina & Suriano and Incorvaia (1995) \\
\hline Demidospermus annulus Marcotegui et Martorelli, 2011 & Parapimelodus valenciennis (Lütken) & Argentina & Marcotegui and Martorelli (2011) \\
\hline Demidospermus araguaiaensis Cepeda et Luque, 2010 & $\begin{array}{l}\text { Brachyplatystoma filamentosum } \\
\text { (Lichtenstein) }\end{array}$ & Brazil & Cepeda and Luque (2010) \\
\hline Demidospermus armostus Kritsky et Gutiérrez, 1998 & Pimelodus clarias (Linnaeus) & Argentina & Kritsky and Gutiérrez (1998) \\
\hline Demidospermus bidiverticulatum (Suriano et Incorvaia, 1995) & Pimelodus clarias and Pimelodus albicans & Argentina & Kritsky and Gutiérrez (1998) \\
\hline Demidospermus brachyplatystomae Cepeda et Luque, 2010 & Brachyplatystoma filamentosum & Brazil & Cepeda and Luque (2010) \\
\hline $\begin{array}{l}\text { Demidospermus brevicirrus Mendoza-Palmero, Scholz, } \\
\text { Mendoza-Franco et Kuchta, } 2012\end{array}$ & Pimelodus sp. & Peru & Mendoza-Palmero et al. (2012) \\
\hline Demidospermus ceccarelli Cepeda et Luque, 2010 & Brachyplatystoma filamentosum & Brazil & Cepeda and Luque (2010) \\
\hline Demidospermus corcinus Kritsky et Gutiérrez, 1998 & Iheringichthys westermanni (Lütken) & Argentina & Kritsky and Gutiérrez (1998) \\
\hline $\begin{array}{l}\text { Demidospermus curvovaginatus Mendoza-Palmero } \\
\text { et Scholz, } 2011\end{array}$ & Pimelodus sp. & Peru & Mendoza-Palmero and Scholz (2011) \\
\hline $\begin{array}{l}\text { Demidospermus ichthyocercus Monteiro, Kritsky et Brasil- } \\
\text { Sato, } 2010\end{array}$ & Pimelodus maculatus & Brazil & Monteiro et al. (2010) \\
\hline Demidospermus idolus Kritsky et Gutiérrez, 1998 & Pimelodus albicans & Argentina & Kritsky and Gutiérrez (1998) \\
\hline Demidospermus lebedevi (Kritsky et Thatcher, 1976) & Pimelodus grosskopfii Steindachner & Colombia & Mendoza-Palmero and Scholz (2011) \\
\hline Demidospermus leptosynophallus Kritsky et Gutiérrez, 1998 & Iheringichthys westermanni & Argentina & Kritsky and Gutiérrez (1998) \\
\hline Demidospermus lucky (Kritsky, Thatcher et Boeger, 1987) & Pinirampus pirinampu (Spix et Agassiz) & Brazil & Kritsky and Gutiérrez (1998) \\
\hline Demidospermus macropteri Mendoza-Franco et Scholz, 2009 & Calophysus macropterus (Lichtenstein) & Peru & Mendoza-Franco and Scholz (2009) \\
\hline Demidospermus majusculus Kritsky et Gutiérrez, 1998 & Pimelodus albicans & Argentina & Kritsky and Gutiérrez (1998) \\
\hline $\begin{array}{l}\text { Demidospermus mortenthaleri Mendoza-Palmero, Scholz, } \\
\text { Mendoza-Franco et Kuchta, } 2012\end{array}$ & Brachyplatystoma juruense (Boulenger) & Peru & Mendoza-Palmero et al. (2012) \\
\hline Demidospermus paravalenciennesi Gutiérrez et Suriano, 1992 & Pimelodus clarias & Argentina & Gutiérrez and Suriano (1992) \\
\hline Demidospermus peruvianus Mendoza-Palmero et Scholz, 2011 & Pimelodus ornatus Kner & Peru & Mendoza-Palmero and Scholz (2011 \\
\hline Demidospermus pinirampi (Kritsky, Thatcher et Boeger, 1987) & Pinirampus pirinampu & Brazil & Kritsky and Gutiérrez (1998) \\
\hline Demidospermus striatus Mendoza-Palmero et Scholz, 2011 & Pimelodus sp. & Peru & Mendoza-Palmero and Scholz (2011 \\
\hline Demidospermus uncusvalidus Gutiérrez et Suriano, 1992 & Pimelodus clarias & Argentina & Gutiérrez and Suriano (1992) \\
\hline Demidospermus valenciennesi Gutiérrez et Suriano, 1992 & Parapimelodus valenciennis & Argentina & Gutiérrez and Suriano (1992) \\
\hline $\begin{array}{l}\text { Pavanelliella jarii Aguiar, Maia, Silva, Ceccarelli, } \\
\text { Domingues et Adriano, } 2017\end{array}$ & Brachyplatystoma rousseauxii (Castelnau) & Brazil & Aguiar et al. (2017) \\
\hline Pavanelliella laertei Aguiar, Ceccarelli et Luque, 2011 & Pimelodus heraldoi Azpelicueta & Brazil & Aguiar et al. (2011) \\
\hline Pavanelliella pavanellii Kritsky et Boeger, 1998 & $\begin{array}{l}\text { Pseudoplatystoma corruscans } \\
\text { (Spix et Agassiz) }\end{array}$ & Brazil & Kritsky and Boeger (1998) \\
\hline Pavanelliella takemotoi Aguiar, Ceccarelli et Luque, 2011 & Pimelodus maculatus & Brazil & Aguiar et al. (2011) \\
\hline Unibarra paranoplatensis Suriano et Incorvaia, 1995 & Paulicea luetkeni Steindachner & Argentina & Suriano and Incorvaia (1995) \\
\hline Urocleidoides amazonensis Mizelle et Kritsky, 1969 & $\begin{array}{l}\text { Phratocephalus hemiliopterus (Block } \\
\text { et Schneider) }\end{array}$ & Brazil & Mizelle and Krisky (1969) \\
\hline Urocleidoides catus Mizelle et Kritsky, 1969 & Phratocephalus hemiliopterus & Brazil & Mizelle and Krisky (1969) \\
\hline Urocleidoides megorchis Mizelle et Kritsky, 1969 & Sorubim lima & Argentina & Mizelle and Krisky (1969) \\
\hline Vancleavus cicinnus Kritsky, Thatcher et Boeger, 1986 & Phractocephalus hemioliopterus & Brazil & Kritsky et al. (1986) \\
\hline Vancleavus fungulus Kritsky, Thatcher et Boeger, 1986 & Pseudoplatystoma tigrinum (Valenciennes) & Brazil & Kritsky et al. (1986) \\
\hline Vancleavus platyrhynchi Kritsky, Thatcher et Boeger, 1986 & $\begin{array}{l}\text { Hemisorubim platyrhynchos } \\
\text { (Valenciennes) }\end{array}$ & Brazil & Kritsky et al. (1986) \\
\hline
\end{tabular}




\section{MATERIAL AND METHODS}

\section{Sampling and morphological evaluation}

Three specimens of Sorubim lima (field codes PI 526a, 598, 862a; PI = Peru, Iquitos,) were captured in the Nanay River in the municipality of Iquitos, Loreto Region, Peru in October 2009, 2011 and 2018. A total of 19 Hemisorubim platyrhynchos and $26 \mathrm{~S}$. lima were sampled using gill nets and multifilament cast nets in the Aguapeí River $\left(21^{\circ} 03^{\prime} 36^{\prime \prime} \mathrm{S}, 51^{\circ} 45^{\prime} 39^{\prime \prime} \mathrm{W}\right)$, a tributary of the Paraná River, in the municipality of Castilho, São Paulo State, Brazil, from August 2013 to November 2014, and in January 2016. The hosts from Brazil were collected under the license number 577/2015 IBAMA (Brazilian Institute of Environment and Renewable Natural Resources).

After capture, some fishes from Brazil were frozen and later examined in the laboratory, whereas others were examined in situ, having the gills removed from the carcases, fixed with hot water $\left(\mathrm{cca} .60^{\circ} \mathrm{C}\right)$, shaken and preserved in vials with $95 \%$ ethanol. To study the morphology of sclerotised structures of the haptor and copulatory complexes, some specimens were mounted on slides with Hoyer's medium and the coverslip was sealed with nail polish. Alive worms were mounted in a mixture of glycerine and picric acid (GAP) and after their morphological evaluation, they were remounted in Canada balsam following the procedure of Ergens (1969). Some specimens were stained with Gomori's trichrome to study their internal organs (Kritsky et al. 1986).

Parasites were studied using an optical microscope (Olympus BX51) equipped with phase contrast optics and V3 Leica Application Suite computerised system for image analysis with differential interference contrast. Illustrations were made with the aid of a drawing tube mounted on a Leica DMLS microscope. Measurements were taken according to Mizelle and Klucka (1953) and Kritsky et al. (1985); they represent straight lines between extreme points and are expressed in micrometres as the range followed by mean and number of specimens measured in parentheses. Hook pairs are numbered according to Mizelle (1936).

Type specimens and vouchers are deposited in the Helminthological Collection of the Institute of Parasitology, Biology Centre of the Czech Academy of Sciences, České Budějovice, Czech Republic (IPCAS), Helminthological Collection of the Institute Oswaldo Cruz, Rio de Janeiro, Brazil (CHIOC), and Helminthological Collection of the Instituto de Biociências, Universidade Estadual Paulista, Botucatu, Brazil (CHIBB).

For comparative purposes, the following specimens were studied: Demidospermus araguaiaensis Cepeda et Luque, 2010 (paratypes - CHIOC 37327); Demidospermus brachyplatystomae Cepeda et Luque, 2010 (paratypes - CHIOC 37321a-b); Demidospermus ceccarellii Cepeda et Luque, 2010 (paratypes - CHIOC 37324a-d); Demidospermus curvovaginatus Mendoza-Palmero et Scholz, 2011 (holotype and paratypes - IPCAS M-513); Demidospermus striatus Mendoza-Palmero et Scholz, 2011 (holotype and paratypes - IPCAS M-514); and Demidospermus mortenhaleri Mendoza-Palmero, Scholz, Mendoza-Franco et Kuchta, 2012 (holotype and paratypes - IPCAS M-522).

\section{Molecular characterisation}

Partial sequences of the 28S rRNA gene of the type species of Nanayella gen. n. (Dactylogyridae gen. sp. 12 of Mendoza-Palmero et al. 2015; KP056228) and another three new species of Nanayella (former Dactylogyridae gen. sp. 3 from S. lima and Dactylogyridae gen. sp. 1 and 2 from H. platyrhynchos of Acosta et al. 2018; MG001327, MG001325 and MG001328, respectively) were analysed. Partial sequences of the $28 \mathrm{~S}$ rRNA gene of three isolates of Urocleidoides megorchis (1,443-1,473 bp long) from S. lima collected in the Peruvian Amazon and two isolates of Aphanoblastella travassosi (Price, 1938) (type species of the genus) from Rhamdia guatemalensis (Günther) (Heptapteridae) collected in Lake Catemaco, Veracruz, Mexico, were newly generated in the present study.

The specimens used for molecular characterisation were cut in half with fine needles. The anterior part of the body containing the male copulatory organ (MCO) and vagina was mounted in a mixture of glycerine and picric acid (GAP) for morphological identification, then remounted in Canada balsam following the procedure of Ergens (1969) and deposited as molecular vouchers (hologenophores, see Pleijel et al. 2008 for terminology). Sequencing followed the procedure outlined by Acosta et al. (2018).

\section{Phylogenetic analyses}

A total of 43 partial sequences of the 28S rRNA gene of dactylogyrid parasites from siluriforms previously published (Mendoza-Palmero et al. 2015, Acosta et al. 2017, 2018, Franceschini et al. 2018, Yamada et al. 2018) along with three species of the Diplectanidae (used as outgroup), were retrieved from GenBank (see Fig. 5) and aligned with the longest newly generated sequences of U. megorchis and A. travassosi. Forty-seven sequences (720-1,575 bp long) were aligned using default parameters of MAFFT implemented in Geneious version 11.1.4 (Kearse et al. 2012); the extremes were trimmed leaving an alignment of $800 \mathrm{bp}$ long.

Phylogenetic analyses were run under Maximum Likelihood (ML) and Bayesian Inference (BI) criteria, applying the model of nucleotide evolution GTR + I + G, selected by JModelTest 2.1.1 (University of Vigo and University of A Coruña, Spain), Darriba et al. (2012). ModelTest analyses were carried out using RAxML (Guindon and Gascuel 2003). Model parameters and bootstrap support values (1,000 repetitions) were estimated using RAxML. Bayesian Inference trees were created using MrBayes (Ronquist et al. 2012), running two independent MCMC runs of four chains for 10 million generations and sampling tree topologies every 1,000 generations. Burn-in periods were set to the first 25,000 generations. Both ML and BI analyses were performed on the computational resource CIPRES (Miller et al. 2010). Genetic divergence was calculated using uncorrected p-distances model in MEGA (Kimura 1980, Tamura et al. 2013). Phylogenetic trees were edited in the software Molecular Evolution, Phylogenetics and Epidmiology - FigTree v1.4.4, Rambaut (2009).

\section{RESULTS}

\section{Nanayella gen. $\mathbf{n}$.}

Zoobank number for genus:

urn:1sid:zoobank.org:act:4B7A4CBA-7F42-44D3-9518-58B4C72A84BD

Diagnosis. Dactylogyridae, Ancyrocephalinae. Body divided into cephalic region, trunk, peduncle and haptor. Tegument thin, surface smooth. Head organs and cephalic lobes present; cephalic glands unicellular, comprising 2 bi- 
lateral groups posterolateral to pharynx. Eyespots absent, subspherical granules scattered in anterior region. Mouth subterminal, midventral; pharynx muscular, glandular; oesophagus present; intestinal caeca 2 , confluent posterior to testis, lacking diverticula. Genital pore midventral, near level of intestinal bifurcation. Gonads in tandem, intercaecal; testis posterior to ovary; ovary folding on itself in ventral/dorsal direction, bent dorsoventrally. Vas deferens looping left intestinal caecum, forming thick-walled seminal vesicle. Copulatory complex comprising tubular J-shaped or coiled male copulatory organ (MCO), margin with fringes and lateral flap when ornamented; coil (when present) of MCO counterclockwise. Accessory piece composed of single unit with variable folds, articulated or not to base of MCO. Genital pore midventral, at level of intestinal bifurcation. Seminal receptacle at level of anterior margin of ovary; vaginal pore sinistrolateral, vagina sclerotised with funnel-shaped distal atrium; sclerotised ornamented atrium present or absent; sclerotised spines as part of ornamented atrium present or absent. Vitelline follicles scattered throughout trunk, except in regions of reproductive organs. Haptor armed with 2 pairs of anchors (dorsal and ventral), 14 hooks with ancyrocephaline distribution (see Mizelle 1936). Ventral and dorsal bars present. Anchors robust, moderately developed superficial roots and inconspicuous deep roots, anchor points extending beyond anchor base. Ventral and dorsal bars bowed or broadly Uand V-shaped. Hooks variable in shape and size, pairs 5 and 6 modified - slender shank proximally enlarged, straight points, inconspicuous thumb; other pairs - recurved point, erect thumb. Parasites of Neotropical catfishes (Pimelodidae).

Type species: Nanayella aculeatrium gen. n. et sp. n.

Additional species: Nanayella fluctuatrium gen. n. et sp. n., Nanayella amplofalcis gen. n. et sp. n., Nanayella processusclavis gen. n. et sp. n., Nanayella megorchis comb. n.

Ety mology: The new genus is named according to the locality (Nanay River, a tributary of the Amazon River in Iquitos, Peru), where its type species was found; this name is appended to the diminutive (-ella) and should be treated as feminine.

Remarks. Nanayella gen. n. differs from all other dactylogyrid genera mainly by the possession of modified hook pairs 5 and 6 , which have a slender shank with slightly enlarged base, inconspicuous thumb, and straight point. The diagnosis of the new genus most closely resembles that of the Neotropical genus Demidospermus, the species of which parasitise auchenipterids, loricariids and mostly pimelodids (23 of 30 species of the genus; see Table 1 for parasite-host interactions). Species of both genera share gonads in tandem, MCO counterclockwise, vaginal aperture sinistral, with a distal variably sclerotised vestibule (or atrium), bars U- or V-shaped, and hooks variable in shape and size. However, both genera differ from each other by different shape of hook pairs 5 and 6 , and the presence of ovary folding on itself in ventral/dorsal direction, which has never been reported in any species of Demidospermus.

Modified hook pairs 5 and 6 with slender shank slightly enlarged at base, inconspicuous thumb, and straight point were also reported in species originally placed in the genus Urocleidoides Mizelle et Price, 1964, which is still pending revision, namely Urocleidoides amazonensis Mizelle et Kritsky, 1969, Urocleidoides catus Mizelle et Kritsky, 1969, and Urocleidoides megorchis (see Mizelle and Kritsky 1969). These three dactylogyrid species are parasites of South American pimelodids and were considered incertae sedis by Kritsky et al. (1986). Based on the presence of morphological characteristics typical of the new genus and molecular evidence, U. megorchis is transferred to the new genus as Nanayella megorchis (Mizelle et Kritsky, 1969) comb. n. (see Remarks to the individual species below).

The proposal of the new genus is also supported by the results of the phylogenetic analyses of the partial sequences of the 28S rRNA gene (Fig. 5). The sequences of the four species described herein together with sequences of $U$. megorchis collected in Peru in 2018 form a monophyletic clade supported by Bayesian Inference (BI) and Maximum Likelihood (ML) within a bigger clade including species of the polyphyletic Demidospermus from pimelodids (Demidospermus mortenthaleri Mendoza-Palmero, Scholz, Mendoza-Franco et Kuchta, 2012, Demidospermus sp. 11 and Demidospermus sp. 23) and Dactylogyridae gen. spp. from pimelodids of Mendoza-Palmero et al. (2015) (see Fig. 5).

\section{Nanayella aculeatrium gen. $n$. et sp. n. - type species}

Fig. 1

Zoobank number for species:

urn:lsid:zoobank.org:act:BD98AD43-581A-4B7F-B78D-6375BDED3E2F

Description (based on ten specimens fixed in GAP and four stained with Gomori's trichrome). Body fusiform, 293-326 (307; $\mathrm{n}=4$ ) long, maximum width 44-59 (49; $\mathrm{n}=4$ ) at mid-length. Cephalic lobes poorly developed; 4 bilateral head organs. Few subspherical granules scattered from cephalic lobes to level of male copulatory organ. Pharynx spherical, 20-21 (20; $\mathrm{n}=3)$ long, 17-18 (17; $\mathrm{n}=3$ ) wide; oesophagus short; intestinal caeca confluent posterior to testis. Peduncle short; haptor subhexagonal, 43-49 (45; n = 4) long, 52-67 (57; n = 4) wide.

Anchors similar in shape, robust shaft, point evenly curved, extending beyond anchor base, base broad, deep root inconspicuous, superficial root moderately developed, double anchor filament present; ventral anchor 30-33 (31; $\mathrm{n}=10)$ long, base $17-20(18 ; \mathrm{n}=10)$ wide; dorsal anchor $25-28(27 ; n=10)$, base $14-17(15 ; n=10)$ wide. Ventral bar bowed, with posteromedial reduced process directed anteriorly, ends directed posteriorly, 30-40 (35; $\mathrm{n}=10)$ long; dorsal bar broadly V-shaped, expanded ends directed posteriorly, 29-34 (32; $\mathrm{n}=10)$ long.

Two types of hook pairs (Fig. 1F-I); pairs 5 and 6 similar, 21-23 (22; $n=6)$ long (Fig. 1F), slender shank slightly enlarged at base, straight shaft and point, inconspicuous thumb; round weakly sclerotised subunit at base present, filamentous hooklet (FH) loop about 3/4 of shank length; pairs 1-4 and 7 similar in shape, slender shank slightly enlarged at base, straight shaft and recurved point, erect thumb, FH loop about $3 / 4$ of shank length; round weakly sclerotised subunit 


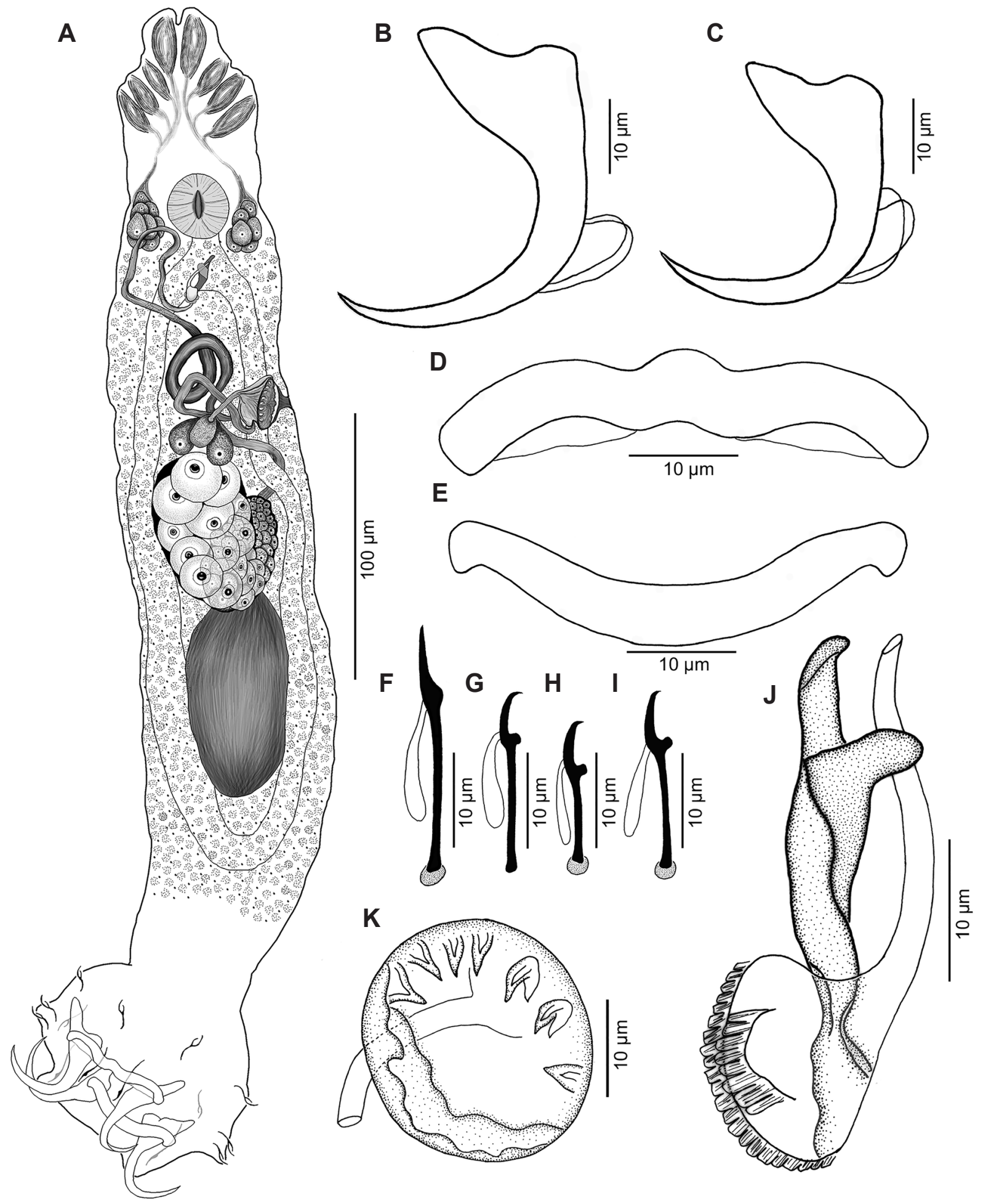

Fig. 1. Nanayella aculeatrium gen. n. et sp. n. from the gills of Sorubim lima (Bloch et Schneider), Peru. A - whole mount (ventral view; composition); B - ventral anchor; $\mathbf{C}$ - dorsal anchor; $\mathbf{D}$ - ventral bar; $\mathbf{E}$ - dorsal bar; $\mathbf{F}$ - hook pairs 5 and 6 with presence of round, weakly, sclerotised subunit at base; $\mathbf{G}$ - hook pairs 1 and $7 ; \mathbf{H}$ - hook pair 2 with presence of round, weakly sclerotised subunit at base; $\mathbf{I}$ - hook pairs 3 and 4 with presence of round, weakly sclerotised subunit at base; $\mathbf{J}$ - male copulatory complex (ventral view); $\mathbf{K}$ - vagina composed of tube and sclerotised ornamented atrium.

at base present in pairs $2-4$; pairs 1 and $7,15-16(16 ; \mathrm{n}=$ 7) long; pair 2, $12(\mathrm{n}=6)$ long; pairs 3 and 4, 13-14 $(14 ; \mathrm{n}$ =6) long.

MCO 29-32 (30; n = 9) long, J-shaped tube, broad base with peripheral ornamentations (fringes) and lateral flap. Accessory piece, $20-31(23 ; \mathrm{n}=9)$ long, articulated to base of MCO, sheath-like, variable folds along its length, conspicuous flap extending laterally guiding distal part of MCO (Fig. 1J). Testis 45-66 (54; n = 4) long, 20-34 $(25 ; n=4)$ wide; vas deferens with convoluted trajectory to anterior part of body, passing level of MCO (Fig. 1A), 


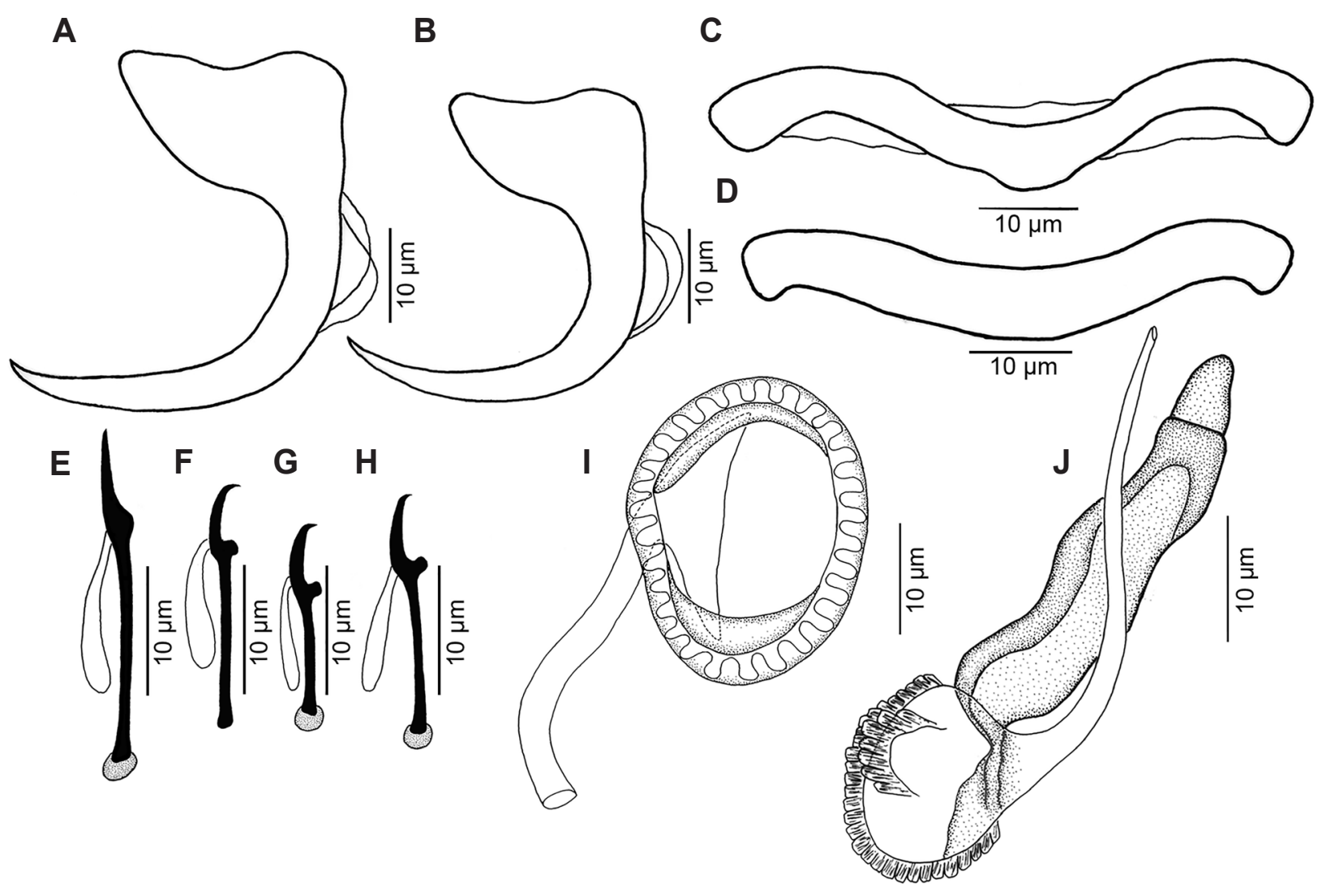

Fig. 2. Sclerotised structures of Nanayella fluctuatrium gen. n. et sp. n. from the gills of Sorubim lima (Bloch et Schneider), Brazil. A - ventral anchor; B - dorsal anchor; $\mathbf{C}$ - ventral bar; D - dorsal bar; $\mathbf{E}$ - hook pairs 5 and 6 with presence of round, weakly sclerotised subunit at base; $\mathbf{F}$ - hook pairs 1 and $7 ; \mathbf{G}$ - hook pair 2 with presence of round, weakly sclerotised subunit at base; $\mathbf{H}-$ hook pairs 3 and 4 with presence of round, weakly sclerotised subunit at base; I - vagina composed of tube and sclerotised ornamented atrium; $\mathbf{J}$ - male copulatory complex (ventral view).

forming thick-walled seminal vesicle in its medial portion; prostatic reservoir not observed.

Ovary 32-38 (36; $\mathrm{n}=4)$ long, 19-24 (21; $\mathrm{n}=4)$ wide; oviduct, ootype, and uterus not observed. Vaginal aperture sinistrolateral, vagina sclerotised, funnel-shaped atrium armed with seven sclerotised robust spines distributed in one half, heavy sclerotised margin in other half (Fig. 1K), connected to short and delicate tube emptying seminal receptacle (Fig. 1A). Vitelline follicles scattered throughout trunk, except in regions of reproductive organs.

Ty p e host: Sorubim lima (Bloch et Schneider) (host codes: PI 526a, 598, 862a).

Type locality: Iquitos - fish market in Belén, Peru $\left(03^{\circ} 46^{\prime} 23^{\prime \prime} \mathrm{S}, 73^{\circ} 18^{\prime} 52^{\prime \prime} \mathrm{W}\right)$.

Site: Gills.

Type material: Holotype (specimen from fish PI 598 collected on 12 October 2009; IPCAS M-694); nine paratypes (IPCAS M-694); hologenophore (IPCAS M-694).

Representative DNA sequence: 925 bp long partial sequence of the 28S rRNA gene (GenBank accession number KP056228; designated as Dactylogyridae gen. sp. 12 by Mendoza-Palmero et al. 2015).

Etymology: The name is from Latin and is related to the presence of spines in the vaginal atrium (aculeus $=$ spine + atrium $=$ atrium).
Remarks. This new species is the type species of the newly erected genus and differs from species of other dactylogyrid genera by the characteristics mentioned in the diagnosis of the new genus (see above). Nanayella aculeatrium gen. n. et sp. n. differs from Nanayella megorchis comb. n. (both from $S$. lima) mainly by the shape of the MCO that is J-shaped in the first versus counterclockwise coiled (2-3 rings) in the latter. The vaginal atrium of $N$. megorchis contains many small and delicate sclerotised spines whereas that of $N$. aculeatrium has only seven sturdy spines of different shape (see Mizelle and Kritsky 1969 for description of U. megorchis).

Nanayella fluctuatrium gen. n. et sp. n.

Fig. 2

Zoobank number for species:

urn:Isid:zoobank.org:act:E0A58860-2F8E-4914-9C48-4B01D67822D9

Description (based on 20 specimens fixed in Hoyer's medium and nine stained with Gomori's trichrome). Body fusiform, 341-496 $(418 ; \mathrm{n}=9)$ long, maximum width 90 $131(104 ; n=9)$ at mid-length. Cephalic lobes poorly developed; four bilateral head organs. Subspherical accessory granules scattered in anterior region. Pharynx spherical 27-31 (29; n = 9) long, 25-34 (29; $\mathrm{n}=9)$ wide; oesophagus short; intestinal caeca confluent posterior to testis. Pe- 
A
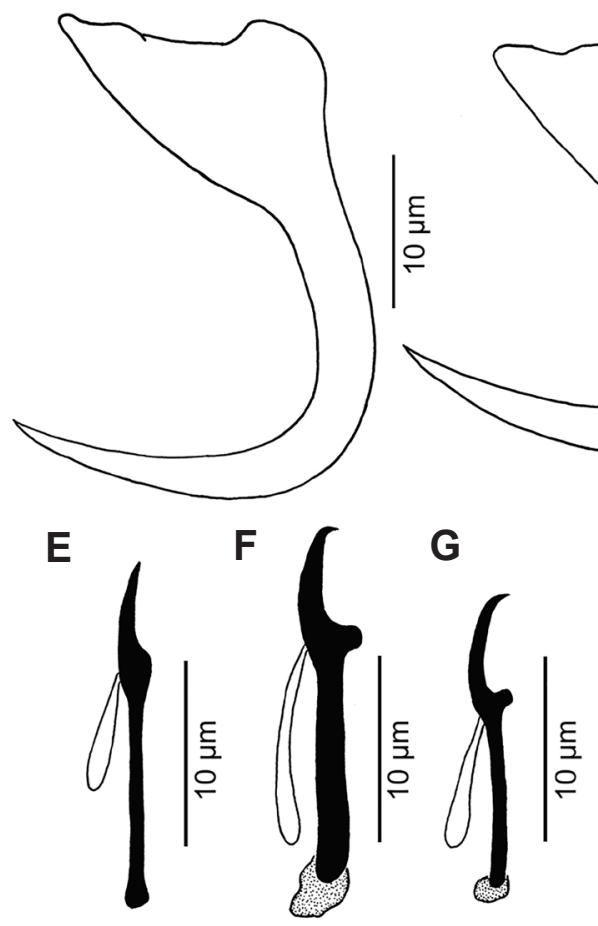

B

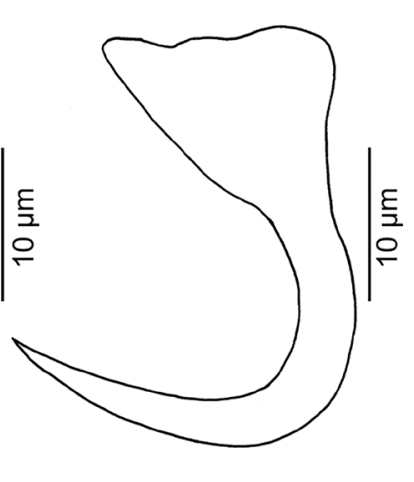

C

D

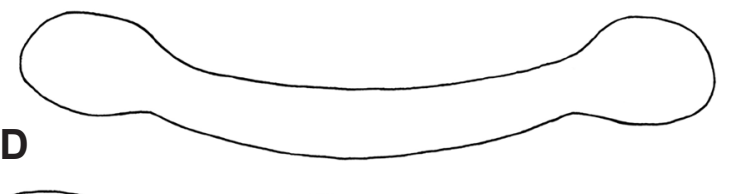

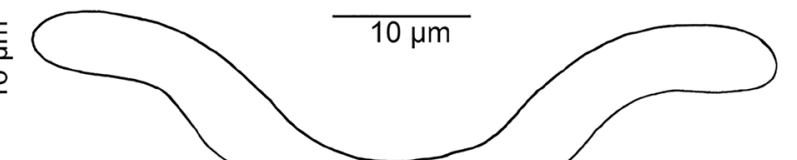

H

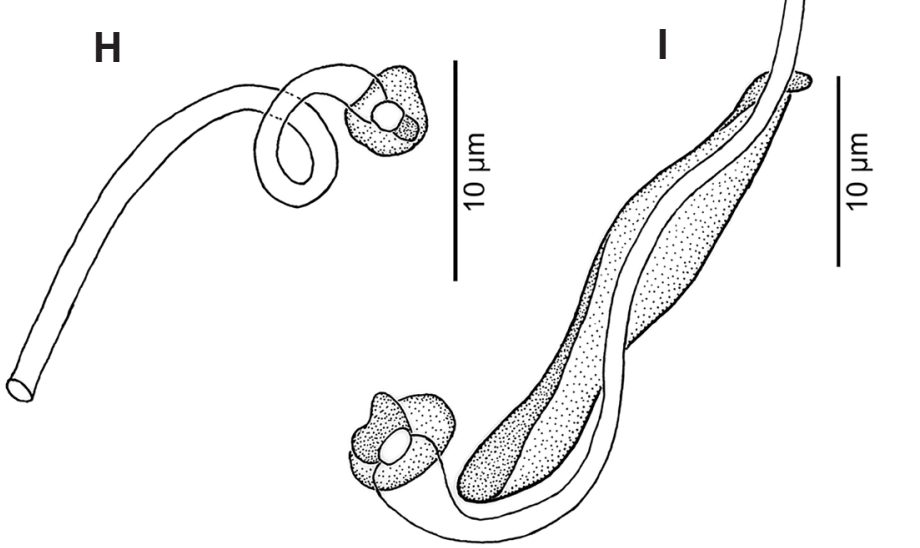

Fig. 3. Sclerotised structures of Nanayella amplofalcis gen. n. et sp. n. from the gills of Hemisorubim platyrhynchos (Valenciennes), Brazil. A - ventral anchor; B - dorsal anchor; $\mathbf{C}$ - ventral bar; $\mathbf{D}$ - dorsal bar; $\mathbf{E}$ - hook pairs 5 and 6 ; $\mathbf{F}$ - hook pairs 1 and 2 with presence of round, weakly sclerotised subunit at base; $\mathbf{G}$ - hook pairs 3, 4 and 7 with presence of round, weakly sclerotised subunit at base; $\mathbf{H}$ - vaginal tube; I - male copulatory complex (ventral view).

duncle short; haptor subhexagonal 36-48 $(41 ; \mathrm{n}=6)$ long, 49-66 $(56 ; \mathrm{n}=6)$ wide.

Anchors similar in shape, robust shaft, point evenly curved extending beyond anchor base, inconspicuous deep and superficial roots, double anchor filament present; ventral anchor 27-35 (31; $\mathrm{n}=20)$ long, base 17-22 $(20 ; \mathrm{n}=$ 18) wide; dorsal anchor 25-31 (28; $\mathrm{n}=20)$, base $13-18$ $(16 ; n=19)$ wide. Ventral bar bowed, with delicate membranes in both anterior and posterior borders, ends directed posteriorly, inconspicuous medial process, 41-56 (48; $\mathrm{n}=19)$ long; dorsal bar bowed, expanded ends directed posteriorly, 34-48 (43; $\mathrm{n}=20)$ long.

Two types of hooks (Fig. 2E-H); pairs 5 and 6 similar, 21-23 (22; $n=6)$ long, slender shank slightly enlarged at base, straight shaft and point, inconspicuous thumb, round weakly sclerotised subunit at base present, FH loop about 3/4 of shank length; pairs $1-4$ and 7 similar in shape, slender shank slightly enlarged at base, straight shaft and recurved point, erect thumb, FH loop about 3/4 of shank length; round weakly sclerotised subunit at base present in pairs 2-4; pairs 1 and 7, 15-16 (16; $\mathrm{n}=7)$ long; pair 2, 12 $(\mathrm{n}=6)$ long; pairs 3 and 4, 13-14 $(14 ; \mathrm{n}=6)$ long.

MCO 32-46 (40; $n=18)$ long, sigmoid tube, tapering in distal end, broad rounded base with ornamentations (fringes), lateral flap at base. Accessory piece 26-36 (32; n=19) long, articulated to base of MCO, straight to sigmoid, sheath-like guiding distal part of MCO (Fig. 3J). Testis
69-101 (83; $\mathrm{n}=5)$ long, 41-77 (55; $\mathrm{n}=5)$ wide; vas deferens sinuous, forming in its medial portion a thick-walled seminal vesicle; prostatic reservoir not observed.

Ovary 44-66 (59; $\mathrm{n}=5)$ long, 27-41 (33; $\mathrm{n}=5)$ wide; oviduct, ootype and uterus not observed. Vaginal aperture sinistrolateral, vagina sclerotised, funnel-shaped atrium with sclerotised undulated ornamentations along its margin (Fig. 2I), connected with short and delicate tube emptying seminal receptacle. Vitelline follicles scattered throughout trunk, except around reproductive organs.

Type host: Sorubim lima (Bloch et Schneider) (host codes Aguapeí - S. lima: 1-6 Ago/13; 1-8 Jan/14; 1-3 Jun/14; 1-6 Nov/14; $1-3$ Jan/16).

Type locality: Aguapeí River (Upper Paraná River basin), municipality of Castilho, São Paulo State, Brazil (213'36"S, $\left.51^{\circ} 45^{\prime} 39^{\prime \prime}\right)$.

Site: Gills.

Type material: Holotype (specimen from fish No. 3 collected on 22 January 2016; IPCAS M-695); four paratypes (IPCAS M-695); six paratypes (CHIOC 40001-4, 40005a-b); five paratypes (CHIBB 378-382L); paragenophore (IPCAS M-695).

Representative DNA sequence: 1,560 bp long partial sequence of the 28S rRNA gene (MG001327; designated as Dactylogyridae gen. sp. 3 by Acosta et al. 2018).

Etymology: The name is from Latin and is related to the presence of sclerotised undulations in the vaginal atrium (fluctus $=$ wave + atrium $=$ atrium $)$. 
Remarks. Nanayella fluctuatrium gen. n. et sp. n. differs from $N$. megorchis and $N$. aculeatrium mainly by the shape of the vagina that does not possess sclerotised spines but rather sclerotised undulations along its margin (see Figs. 1K, 2I in the present paper and figs. 56-64 in Mizelle and Kritsky 1969). Nanayella fluctuatrium differs from $N$. megorchis also by the presence of a sigmoid MCO versus counterclockwise coiled (2-3 rings) in the latter species. The new species also differs from $N$. aculeatrium by having larger ventral and dorsal bars, the medial region of the ventral bar is directed posteriorly, MCO longer, and absence of a lateral flap of the accessory piece (see Figs. $1 \mathrm{~J}, 2 \mathrm{~J})$.

Nanayella amplofalcis gen. $\mathrm{n}$. et sp. n.

Fig. 3

Zoobank number for species:

urn:1sid:zoobank.org:act:45D023B3-7CF5-4F4B-A75F-FC70E5D00B9E

Description (based on 24 specimens fixed in Hoyer's medium and six stained with Gomori's trichrome). Body fusiform, 230-322 (270; $\mathrm{n}=6)$ long, maximum width 38-62 $(49 ; n=6)$ at mid-length. Cephalic lobes poorly developed; four bilateral head organs. Subspherical granules scattered in cephalic region. Pharynx spherical, 14-19 $(16 ; \mathrm{n}=4)$ long, 13-19 (15; $\mathrm{n}=4)$ wide; oesophagus short; intestinal caeca confluent posterior to testis. Peduncle long; haptor subhexagonal, 39-50 (44; $\mathrm{n}=5)$ long, 50-52 (51; $\mathrm{n}=5)$ wide.

Anchors similar in shape and size, point evenly curved extending beyond anchor base, broad base, lateral filaments absent, poorly differentiated roots. Ventral anchor 25-28 (27; $\mathrm{n}=24)$, base $12-15(14 ; \mathrm{n}=24)$ wide; dorsal anchor 23-26 (24; $\mathrm{n}=24)$ long, base $12-14(13 ; \mathrm{n}=24)$ wide. Ventral bar 34-48 $(43 ; \mathrm{n}=20)$ long, slightly bowed with expanded ends; dorsal bar 45-53 (49; $\mathrm{n}=21)$ long, open V-shaped, rounded ends directed laterally, inconspicuous posterior medial process represented by a strongly sclerotised patch (Fig. 3D).

Hooks of 3 types (Fig. 3E-G); pairs 5 and 6 equal 16-17 $(17 ; n=13)$ long, shank slender, slightly enlarged at base, straight shaft and point, inconspicuous thumb, FH loop about $1 / 2$ of shank length; pairs 1 and 2 equal $16-17(17 ; n=14)$ long, straight shaft and recurved point, erect thumb, robust wide shank, round weakly sclerotised subunit at base absent, FH loop about 3/4 of shank length; pairs 3, 4 and 7 equal 13$14(13 ; n=14)$ long, recurved shaft and point, erect thumb, slender and short shank, FH loop about $3 / 4$ of shank length.

MCO 30-36 $(32 ; n=24)$ long, slightly sinuous tube, tapering distally, semicircular base ornamented with irregular flap. Accessory piece 20-25 (22; $\mathrm{n}=19)$ long, not articulated with base of $\mathrm{MCO}$, sheath-like, slightly sinuous shaped. Testis $27-35(33 ; \mathrm{n}=3)$ long, 10-13 $(12 ; \mathrm{n}=3)$ wide; vas deferens forming thick-walled seminal vesicle in its medial portion; prostatic reservoir not observed.

Ovary $17-19(18 ; \mathrm{n}=3)$ long, $10-13(12 ; \mathrm{n}=3)$ wide; oviduct, ootype and uterus not observed. Vaginal aperture sinistrolateral, vagina sclerotised leading to delicate coiled vaginal tube. Vitelline follicles dense, coextensive with intestinal caeca.
Type host: Hemisorubim platyrhynchos (Valenciennes) (host codes Aguapeí - H. platyrhynchos 1-3 Ago/13; 1-8 Jan/14; 1-8 Jun/14).

Type locality: Aguapeí River (Paraná River basin), municipality of Castilho, São Paulo State, Brazil (213'36"S, $\left.51^{\circ} 45^{\prime} 39^{\prime \prime}\right)$.

Site: Gills.

Type material: Holotype (specimen from host No. 3 collected on 26 January 2014; IPCAS M-696); 2 paratypes (IPCAS M-696); 6 paratypes (CHIOC 39097a-b, 39098-99; 39100a-b); 6 paratypes (CHIBB 383-388L); paragenophore (IPCAS M-696).

Representative DNA sequence: 1,550 bp long partial sequence of the 28S rRNA gene (MG001325; designated as Dactylogyridae gen. sp. 1 by Acosta et al. 2018).

Etymology: The name is from Latin and is related to the characteristic hook pairs 1 and 2 that possess a wide and robust shank compared to other congeners $($ amplo $=$ wide + falcis $=$ hook $)$.

Remarks. The new species presents unique shape of hook pairs 1 and 2 with a robust, wide shank (Fig. 3F). Nanayella amplofalcis gen. n. et sp. n. can be distinguished from N. megorchis, N. aculeatrium and N. fluctuatrium mainly by the shape of the accessory piece which is not articulated to the base of the MCO whereas it is articulated in the other species of Nanayella from S. lima.

Nanayella processusclavis gen. $\mathrm{n}$. et $\mathrm{sp} . \mathrm{n}$.

Fig. 4

Zoobank number for species:

urn:1sid:zoobank.org:act:43861BAD-3EF8-429B-9F97-F78C534A9819

Description (based on ten specimens fixed in Hoyer's medium and one stained with Gomori's trichrome). Body fusiform 243 long, maximum width 43 at mid-length. Cephalic lobes poorly developed; four bilateral head organs. Accessory granules scattered from cephalic lobes to level of male copulatory organ. Pharynx spherical, 17 long, 15 wide; oesophagus short; intestinal caeca confluent posterior to testis. Peduncle long; haptor subhexagonal, 33 long, 43 wide.

Anchors similar in shape, evenly curved point extending beyond anchor base, broad superficial root, poorly differentiated deep root, double lateral filament; ventral anchor 29-32 (30; $\mathrm{n}=10)$ long, base 15-18 (16; $\mathrm{n}=10)$ wide; dorsal anchor $23-26(25 ; \mathrm{n}=10)$, base $12-14(13 ; \mathrm{n}=10)$ wide. Ventral bar 39-46 (43; n = 9) long, slightly bowed with enlarged ends directed laterally; dorsal bar open V-shaped, 30-37 (33; $\mathrm{n}=8)$ long, short medial process, small sclerotised patch on medial process tip (Fig. 5D).

Two types of hooks (Fig. 4E-G); pairs 5 and 6 equal 23 $(22-23 ; n=12)$ long, slender shank slightly enlarged at base, straight shaft and point, inconspicuous thumb, round weakly sclerotised subunit at base present, FH loop about 1/2 of shank length; pairs 1-4 and 7 similar in shape; slender shank, slightly enlarged at base, recurved point, erect thumb, FH loop about 3/4 of shank length, pairs 1-4, 16 (n =9) long, pair 7, $18(\mathrm{n}=10)$ long. 
A
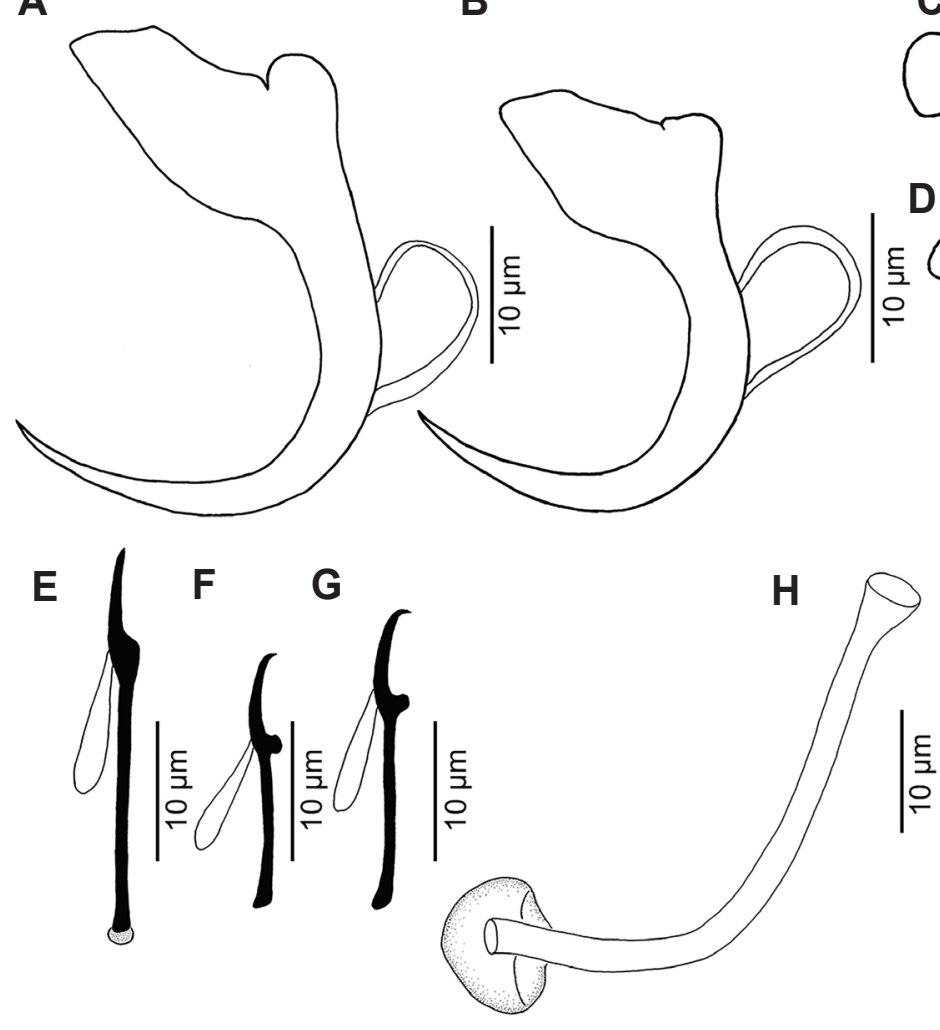

C

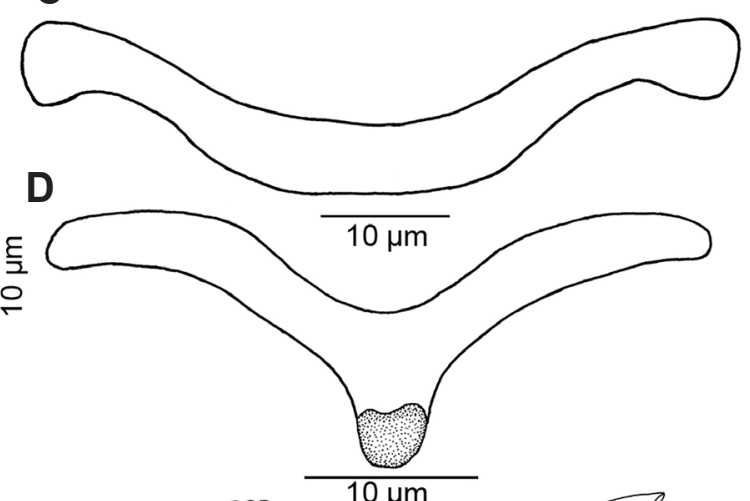

I

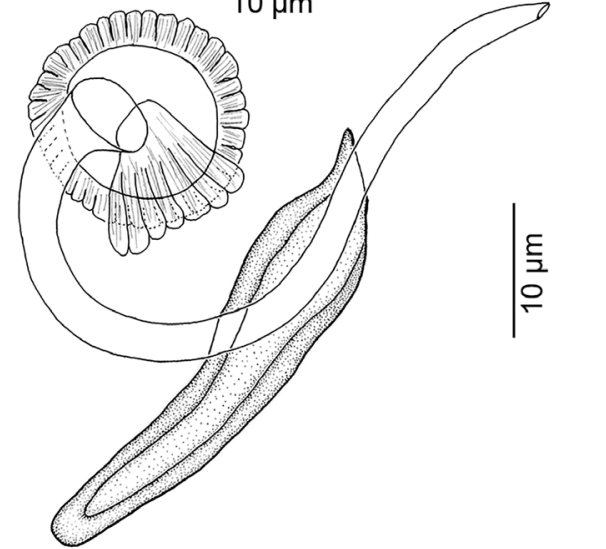

Fig. 4. Sclerotised structures of Nanayella processusclavis gen. n. et sp. n. from the gills of Hemisorubim platyrhynchos (Valenciennes), Brazil. A - ventral anchor; B - dorsal anchor; $\mathbf{C}$ - ventral bar; $\mathbf{D}$ - dorsal bar; $\mathbf{E}$ - hook pairs 5 and 6 with presence of round, weakly sclerotised subunit at base; $\mathbf{F}$ - hook pairs 1-4; $\mathbf{G}$ - hook pair 7; $\mathbf{H}$ - vagina tube with detail of sclerotised ornamentation present at inner end; I - male copulatory complex (ventral view).

Male copulatory organ 35-42 (40; $\mathrm{n}=9)$ long, comprising J-shaped delicate tube, circular broad base with peripheral ornamentations (fringes) and trapezoidal lateral flap. Accessory piece $28-34(30 ; n=9)$ long, sheath-like not articulated to base of $\mathrm{MCO}$, guiding distal part of $\mathrm{MCO}$ (Fig. 4I). Testis 64 long, 19 wide; vas deferens forming thick-walled seminal vesicle in its medial portion, prostatic reservoir not observed.

Ovary 44 long, 15 wide; oviduct, ootype and uterus not observed. Vaginal aperture sinistrolateral, sclerotised ornamentation surrounding inner end of vaginal tube (Fig. 4H). Vitelline follicles dense, scattered throughout trunk, except in regions of reproductive organs.

Type and only known host: Hemisorubim platyrhynchos (Valenciennes) (host codes Aguapeí - H. platyrhynchos 1-3 Ago/13; 1-8 Jan/14; 1-8 Jun/14).

Type locality: Aguapeí River (Paraná River basin), municipality of Castilho, São Paulo State, Brazil (213'36"S, $\left.51^{\circ} 45^{\prime} 39^{\prime \prime} \mathrm{W}\right)$.

Site: Gills.

Type material: Holotype (specimen from host No. 3 collected on 26 January 2014; IPCAS M-697); five paratypes (CHIOC 40006, 40007a-d); five paratypes (CHIBB 389393L); paragenophore (IPCAS M-697).

Representative DNA sequence: 1,550 bp long partial sequence of the 28S rRNA gene (MG001328; designated as Dactylogyridae gen. sp. 2 by Acosta et al. 2018).
Etymology: The name is from Latin and is related to the shape of the medial process of the dorsal bar (processus $=$ process + clavis $=$ bar).

Remarks. The new species differs from the remaining species of the new genus mainly by the presence of a medial process on the dorsal bar (Fig. 4D), and the presence of sclerotised ornamentation surrounding the inner end of the vaginal tube (Fig. 4H). Nanayella processusclavis gen. n. et sp. n. does not present any articulation of the MCO with the accessory piece as in N. amplofalcis, but can be distinguished from the latter by the shape of the MCO, which is J-shaped versus a slightly sinuous tube in N. amplofalcis.

Nanayella megorchis (Mizelle et Kritsky, 1969) comb. n.

S y n o n y m: Urocleidoides megorchis Mizelle et Kritsky, 1969

Type host: Sorubim lima (Bloch et Schneider).

Type locality: La Plata Drainage, Brazil.

New locality: Iquitos, Peru.

Additional material: five vouchers (IPCAS M-698), hologenophore (IPCAS M-698); all collected from S. lima (PI 1058).

Representative DNA sequences: $1,443-1,473$ bp long partial sequences of the 28S rRNA gene of three isolates (GenBank accession numbers: MK367405-07). 


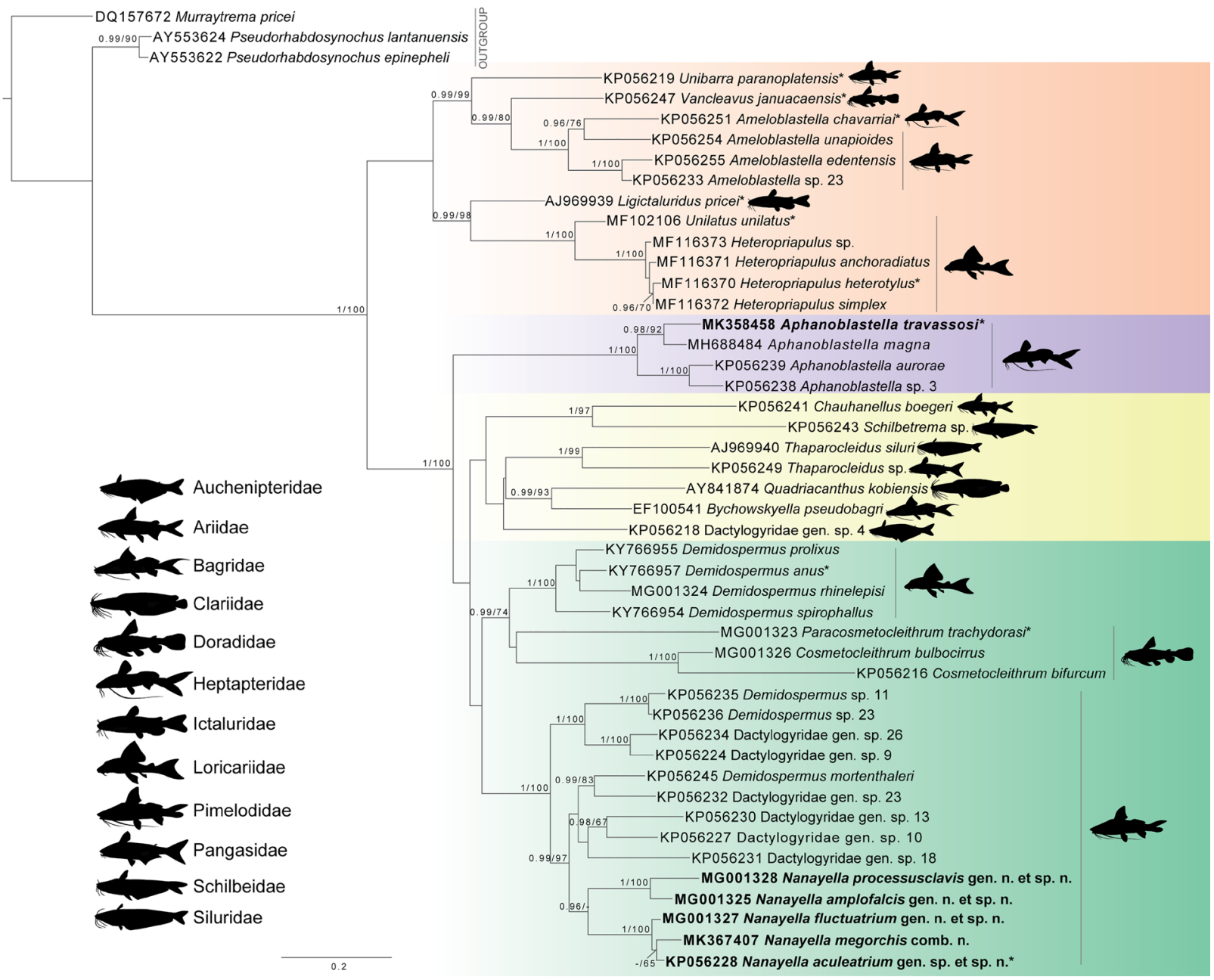

Fig. 5. Maximum likelihood phylogram based on partial sequences of the 28S rRNA gene. Species described in this study and those newly sequenced are in bold. Posterior probability followed by bootstrap support values are given above the branches (posterior probability $<0.90$ and bootstrap $<60$ not shown). Asterisk indicates type-species. Diplectanids were used as outgroup. Branch length scale bar indicates number of substitution per site.

Remarks. Urocleidoides megorchis was described from the gills of S. lima in Brazil by Mizelle and Kritsky (1969). Kritsky et al. (1986) considered this species as incertae sedis together with $U$. amazonensis and $U$. catus found in another pimelodid, redtail catfish, Phractocephalus hemioliopterus (Bloch et Schneider), in the Amazon River Basin, Brazil (see Mizelle and Kritsky 1969). Kritsky et al. (2000) suggested that a new genus should be proposed to accommodate these three species. They all possess modified hook pairs 5 and 6 (slender shank, degenerate thumb, and straight point), in which they resemble species of Nanayella.

Based on the original description and evaluation of new material collected recently in S. lima from Peru, U. megorchis is transferred to Nanayella because it has modified hook pairs 5 and 6 , sclerotised spines in the vaginal atrium, accessory piece composed of a single unit articulated to the base of the MCO, and morphology of ventral and dorsal bars similar to those of species of Nanayella from S. lima (see above). Newly generated molecular data support placement of this species in Nanayella as a new combination.

In contrast, $U$. amazonensis and $U$. catus, which somewhat resemble species of Nanayella in their morphology (see Mizelle and Kritsky 1969), are provisionally retained in Urocleidoides. New material of these species and molecular data can provide evidence whether they also belong to Nanayella.

\section{Phylogenetic analyses}

ML and BI analyses yielded similar tree topology (Fig. 5). Species of Nanayella formed a monophyletic clade sister to the clades composed of D. mortenthaleri with Dactylogyridae gen. sp. 23, and Dactylogyridae gen. sp. 13 with Dactylogyridae gen. sp. 10, and Dactylogyridae gen. sp. 18. Results of ML and BI analyses suggested that interspecific relationships between Nanayella spp. follow a clear pattern of host-parasite associations, i.e., N. aculeatrium, N. fluctuatrium, and $N$. megorchis from $S$. lima form a clade sister to the other composed from two species of $H$. platyrhynchos, i.e. N. amplofalcis and N. processusclavis (Fig. 5).

Genetic divergence in the partial sequences of the $28 \mathrm{~S}$ rRNA gene ranged from 3 to $21 \%$ among the species of Nanayella (i.e. interspecific divergence), from 19 to $25 \%$ among species of Nanayella and those of the polyphyletic Demidospermus from pimelodids and from 25 to $29 \%$ 
among species of Demidospermus from loricariids including its type species Demidospermu anus (Suriano, 1983), and from 17 to $25 \%$ among species of the new genus and unidentified species of Dactylogyridae (Dactylogyridae gen. sp. 9, 10, 13, 18, 23 and 26 of Mendoza-Palmero et al. 2015) from pimelodids (see Supplementary Table 1).

Aphanoblastella travassosi (type species of the genus - GenBank accession number MK358457-58) clustered with a strong support together with Aphanoblastella magna Yamada, Acosta, Yamada, Scholz et da Silva, 2018, Aphanoblastella aurorae Mendoza-Palmero, Scholz, Mendoza-Franco et Kuchta, 2012 and Aphanoblastella Kritsky, Mendoza-Franco et Scholz, 2000 sp. 3. Thus, the monophyly of Aphanoblastella (parasites specific to heptapterid catfishes) is herein supported.

\section{DISCUSSION}

Nanayella gen. n. is proposed to accommodate dactylogyrids of South American pimelodids based on the presence of a unique combination of morphological characteristics and also on molecular evidence (sequences of all four new species). Recent studies on the monogenean fauna of Neotropical siluriforms show that the current knowledge of the diversity of these fish parasites is still underestimated and many species are to be described and genera proposed (Mendoza-Palmero et al. 2012, 2015).

Even though the species of the new genus share morphological characteristics with some species of the polyphyletic Demidospermus, their unique combination together with a distinct position of the four new species in the phylogenetic tree of Neotropical monogeneans from catfishes (Fig. 5) support erection of Nanayella. It cannot be excluded that the morphologically similar species Urocleidoides amazonensis and Urocleidoides catus from South American pimelodids may also belong to the new genus. However, there are still no molecular data available on these taxa and some species of similar morphology previously assigned to the polyphyletic Demidospermus (see Mendoza-Palmero et al. 2015).

Demidospermus is one of the most speciose and taxonomically problematic genera of dactylogyrids from $\mathrm{Ne}$ - otropical siluriforms (families Auchenipteridae, Loricariidae and Pimelodidae), with 30 species described so far (Acosta et al. 2018, Franceschini et al. 2018). Even though most species (23) have been described from pimelodids, it seems that the genus is in fact specific to loricariids and taxa from other catfish families belong to other genera, not yet formally proposed (Mendoza-Palmero et al. 2015, Acosta et al. 2018, Franceschini et al. 2018).

The present study increases the number of records of gill dactylogyrids from Sorubim lima and Hemisorubim platyrhynchos, which are relatively poorly studied fish hosts. The only species known prior to this study were Nanayella megorchis (previously in Urocleidoides) and Ameloblastella unapioides described from S. lima, and Vancleaveus platyrhynchi from $H$. platyrhynchos. The reassignment of Urocleidoides megorchis to Nanayella thus clarifies taxonomic position of one of numerous taxa considered incertae sedis (see Kritsky et al. 1986).

Acknowledgments. A.A.A. was supported by the Institute of Parasitology (RVO: 60077344), Czech Science Foundation (project No. P505/12/G112), and the Fundação de Amparo à Pesquisa do Estado de São Paulo - FAPESP (2012/22895-7; 2015/22382-8). CAMP was funded by a postdoctoral fellowship granted by the Consejo Nacional de Ciencia y Tecnología (CONACyT), Mexico (CVU 168157) and by the Percy Laden Fund, Linnaean Society of London to collect fish parasites in Peru. R.J.S. was supported by CNPq (309125/2017-0) and CNPq-PROTAX (440496/20152) / FAPESP (2016/50377-1). The authors thank the Companhia Energética de São Paulo (CESP) for providing the facilities and logistic support for the field expeditions in the Aguapeí River, Philippe V. Alves (Universidade Federal Rural do Rio de Janeiro, Seropédica, Brazil) for help with molecular analyses, Walter Boeger (Universidade Federal de Paraná, Curitiba, Brazil) for valuable advice, and Marcelo Knoff and Daniela Lopes (CHIOC) for lending paratypes of Demidospermus spp. The authors are also indebted to Roman Kuchta (Institute of Parasitology, České Budějovice, Czech Republic), Alain de Chambrier (Museum of Natural History, Geneva, Switzerland), Andrea Šimková and Eva Řehulková (Masaryk University, Brno, Czech Republic) for their help during fish examination in Iquitos, Peru. The late Martin Mortenthaler, Aurora Ramírez and their staff (Acuario Río Momón) provided invaluable assistance during fieldwork in Peru.

\section{REFERENCES}

Acosta A.A., Franceschini L., Zago A.C., Scholz T., SilVA R.J. 2017: Six new species of Heteropriapulus (Monogenea: Dactylogyridae) from South American fishes with an amended diagnosis to the genus. Zootaxa 4290: 459-482.

Acosta A.A., Scholz T., Blasco-Costa I., Alves P.V., Silva R.J. 2018: A new genus and two new species of dactylogyrid monogeneans from gills of Neotropical catfishes (Siluriformes: Doradidae and Loricariidae). Parasitol. Int. 67: 4-12.

Aguiar J.C., Ceccarelli P.S., Luque J.L. 2011: Two new species of Pavanelliella (Monogenea, Dactylogyridae) parasitic on pimelodid fishes from Mogi Guaçu River, southeastern Brazil, and notes on the morphology of $P$. pavanellii. Neotrop. Helminthol. 5: 213-224.

Aguiar J.C., Maia A.A.M., Silva M.R.M., Ceccarelli P.S., Domingues M.V., Adriano E.A. 2017: An integrative taxonomic study of Pavanelliella spp. (Monogenoidea, Dactylogyri- dae) with the description of a new species from the nasal cavities of an Amazon pimelodid catfish. Parasitol. Int. 66: 777-788.

Cepeda B.P., Luque J.L. 2010: Three new species of Demidospermus (Monogenea: Dactylogyridae) parasitic on Brachyplatystoma filamentosum (Siluriformes: Pimelodidae) from the Araguaia River, Brazil. J. Parasitol. 96: 869-973.

Cohen S.C., Justo M.C.N., Kohn A. (Eds.) 2013: South American Monogenoidea, Parasites of Fishes, Amphibians and Reptiles. Fundação Oswaldo Cruz e Conselho Nacional de Desenvolvimento Científico e Tecnológico, Oficina de Livros, Rio de Janeiro, $663 \mathrm{pp}$.

Darriba D., Taboada G.L., Doallo R., Posada D. 2012: jModelTest 2: more models, new heuristics and parallel computing. Nat. Methods 9: 772.

Eschemeyer W.N., Fricke R., van Der LAan R. 2017: Cata$\log$ of Fishes: Genera, Species, References. World Wide Web 
electronic publication. http://researcharchive.calacademy.org/ research/ichthyology/catalog/fishcatmain.asp

ERGENS R. 1969: The suitability of ammonium picrate-glycerin in preparing slides of lower Monogenoidea. Folia Parasitol. 16: 320.

Franceschini L., Zago A.C., Müller M.I., Francisco C.J., Takemoto R.M., Silva R.J. 2018: Morphology and molecular characterization of Demidospermus spirophallus n. sp., $D$. prolixus n. sp. (Monogenea: Dactylogyridae) and a redescription of $D$. anus in siluriform catfish from Brazil. J. Helminthol. 92: 228-243.

Froese R., Pauly D. 2018: FishBase. World Wide Web electronic publication. www.fishbase.org/search.php

Guindon S., Gascuel O. 2003: A simple, fast, and accurate algorithm to estimate large phylogenies by maximum likelihood. Syst. Biol. 52: 696-704.

GutiérRez P.A., Suriano D.M. 1992: Ancyrocephalids of the genus Demidospermus Suriano, 1983 (Monogenea) parasites from siluriform fishes in Argentina, with descriptions of three new species. Acta Parasitol. 37: 169-172.

Kearse M., Moir R., Wilson A., Stones-Havas S., Cheung M., Sturrock S., Buxton S., Cooper A., Markowitz S., Duran C., Thierer T., Ashton B., Meintues P., DrumMOND A. 2012: Geneious Basic: an integrated and extendable desktop software platform for the organization and analysis of sequence data. Bioinformatics 28: 1647-1649.

KimuRA M. 1980. A simple method for estimating evolutionary rate of base substitutions through comparative studies of nucleotide sequences. J. Mol. Evol. 16: 111-120.

Kritsky D.C., Boeger W.A. 1998: Neotropical Monogenoidea. 35. Pavanelliella pavanellii, a new genus and species (Dactylogyridae, Ancyrocephalinae) from the nasal cavities of siluriform fishes in Brazil, J. Helminthol. Soc. Wash. 65: 160-163.

Kritsky D.C., Boeger W.A., Thatcher V.E. 1985: Neotropical Monogenea. 7. Parasites of pirarucu, Arapaima gigas (Cuvier), with descriptions of two new species and redescription of Dawestrema cycloancistrium Price and Nowlin, 1967 (Dactylogyridae: Ancyrocephalinae). Proc. Biol. Soc. Wash. 98: 321-331.

Kritsky D.C., GutiérRez P.A. 1998: Neotropical Monogenoidea. 34. Species of Demidospermus (Dactylogyridae, Ancyrocephalinae) from the gills of pimelodids (Teleostei, Siluriformes) in Argentina. J. Helminthol. Soc. Wash. 65: 147-159.

Kritsky D.C., Mendoza-Franco E.F., Scholz T. 2000: Neotropical Monogenoidea. 36. Dactylogyrids from the gills of Rhamdia guatemalensis (Siluriformes, Pimelodidae) from cenotes of the Yucatan Peninsula, Mexico, with the proposal of Ameloblastella gen. n. and Aphanoblastella gen. n. (Dactylogyridae, Ancyrocephalinae). Comp. Parasitol. 67: 76-84.

Kritsky D.C., Thatcher V.E., Boeger W.A. 1986: Neotropical Monogenea. 8. Revision of Urocleidoides (Dactylogyridae, Ancyrocephalinae). Proc. Biol. Soc. Wash. 53, 1-37.

LundberG J.G., Littmann M.W. 2003: Family Pimelodidae (long-whiskered catfishes). In: R.E. Reis, S.O. Kullander, C.J. Ferraris Jr. (Eds.), Check List of the Freshwater Fishes of South and Central America. EDIPUCRS, Porto Alegre, pp. 432-446.

Lundberg J.G., Sullivan J.P., Hardman M. 2011: Phylogenetics of the South American catfish family Pimelodidae using nuclear and mitochondrial gene sequences. Proc. Acad. Nat. Sci. Philadelphia 161: 153-189.

Marcotegui P.S., Martorelli S.R. 2011: A new species of Demidospermus (Platyhelminthes, Monogenea, Ancyrocephalidae) from the catfish Parapimelodus valenciennis in Samborombón Bay, Argentina. Acta Parasitol. 56: 116-121.

Mendoza-Franco E.F., Mendoza-Palmero C.A., Scholz T. 2016: New species of Ameloblastella Kritsky, Mendoza-Fran- co \& Scholz, 2000 and Cosmetocleithrum Kritsky, Thatcher \& Boeger, 1986 (Monogenea: Dactylogyridae) infecting the gills of catfishes (Siluriformes) from the Peruvian Amazonia. Syst. Parasitol. 93: 847-862.

Mendoza-Franco E.F., Scholz T. 2009: New dactylogyrids (Monogenea) parasitizing the gills of catfishes (Siluriformes) from the Amazon River basin in Peru. J. Parasitol. 95: 865-870.

Mendoza-Palmero C.A., Blasco-Costa I., Scholz T. 2015: Molecular phylogeny of Neotropical monogeneans (Platyhelminthes: Monogenea) from catfishes (Siluriformes). Parasites Vectors 8: 164.

Mendoza-Palmero C.A., Scholz T. 2011: New species of Demidospermus (Monogenea: Dactylogyridae) of pimelodid catfish (Siluriformes) from Peruvian Amazonia and the reassignment of Urocleidoides lebedevi Kritsky and Thatcher, 1976. J. Parasitol. 97: 586-592.

Mendoza-Palmero C.A., Scholz T., Mendoza-Franco E.F., Kuchta R. 2012: New species and geographical records of dactylogyrids (Monogenea) of catfish (Siluriformes) from the Peruvian Amazonia. J. Parasitol. 98: 484-497.

Miller M.A., Pfeiffer W., Schwartz T. 2010: Creating the CIPRES Science Gateway for inference of large phylogenetic trees. SC10 Workshop on Gateway Computing Environments (GCE10), New Orleans, Louisiana, 14 November 2010, pp. 1-8.

Mizelle J.D. 1936: New species of trematodes from the gills of Illinois fishes. Am. Midl. Nat. 17: 785-806.

Mizelle J.D., Klucka A.R. 1953: Studies on monogenetic trematodes. XIV. Dactylogyridae from Wisconsin fishes. Am. Midl. Nat. 49: 720-733.

Mizelle J.D., KRitSKy D.C. 1969: Studies on monogenetic trematodes. XL. New species from marine and freshwater fishes. Am. Midl. Nat. 82: 417-428

Monteiro C.M., Kritsky D.C., Brasil-Sato M.C. 2010: Neotropical Monogenoidea. 55. Dactylogyrids parasitizing the pintado-amarelo Pimelodus maculatus Lacépède (Actinopterygii: Pimelodidae) from the Rio São Francisco, Brazil. Syst. Parasitol. 76: 179-190.

Pleijel F., Jondelius U., Norlinder E., Nygren A., Oxelman B., Schander C., Sundberg P., Thollesson M. 2008: Phylogenies without roots? A plea for the use of vouchers in molecular phylogenetic studies. Mol. Phylogenet. Evol. 48: 369-371.

Price C.E., Romero N.G. 1969: First account of a monogenetic trematode from Paraguay: Amphocleithrum paraguayensis gen., n. sp. Zool. Jahrbuch. 96: 446-452.

Rambaut A. 2009: Molecular evolution, phylogenetics and epidemiology: Fig-Tree. World Wide Web electronic publication. http//tree. bio.ed.ac.uk/software/figtree/, 07/2018.

Ronquist F., Teslenko M., Van Der Mark P., Ayres D.L., Darling A., Höhna S., Larget B., Liu L., Suchard M.A., Huelsenbeck J.P. 2012: MrBayes 3.2: efficient Bayesian phylogenetic inference and model choice across a large model space. Syst. Biol. 61: 539-542.

Suriano D.M., InCorvaia I.S. 1995: Ancyrocephalid (Monogenea) parasites from siluriform fishes from the Paranean-Platean ichthyogeographical province in Argentina. Acta Parasitol. 40: $113-124$.

Tamura K., Stecher G., Peterson D., Filipski A., Kumar S. 2013: MEGA6: Molecular Evolutionary Genetics Analysis version 6.0. Mol. Biol. Evol. 12: 2725-2729.

Yamada F.H., Acosta A.A., Yamada P.O.F., Scholz T., SilVA R.J. 2018: A new species of Aphanoblastella Kritsky, Mendoza-Franco and Scholz, 2000 (Monogenea, Dactylogyridae) parasitic of heptapterid catfish (Siluriformes) in the Neotropical Region. Acta Parasitol. 63: 772-780.

Cite this article as: Acosta A.A., Mendoza-Palmero C.A., da Silva R.J., Scholz T. 2019: A new genus and four new species of dactylogyrids (Monogenea), gill parasites of pimelodid catfishes (Siluriformes: Pimelodidae) in South America and the reassignment of Urocleidoides megorchis Mizelle et Kritsky, 1969. Folia Parasitol. 66: 004. 